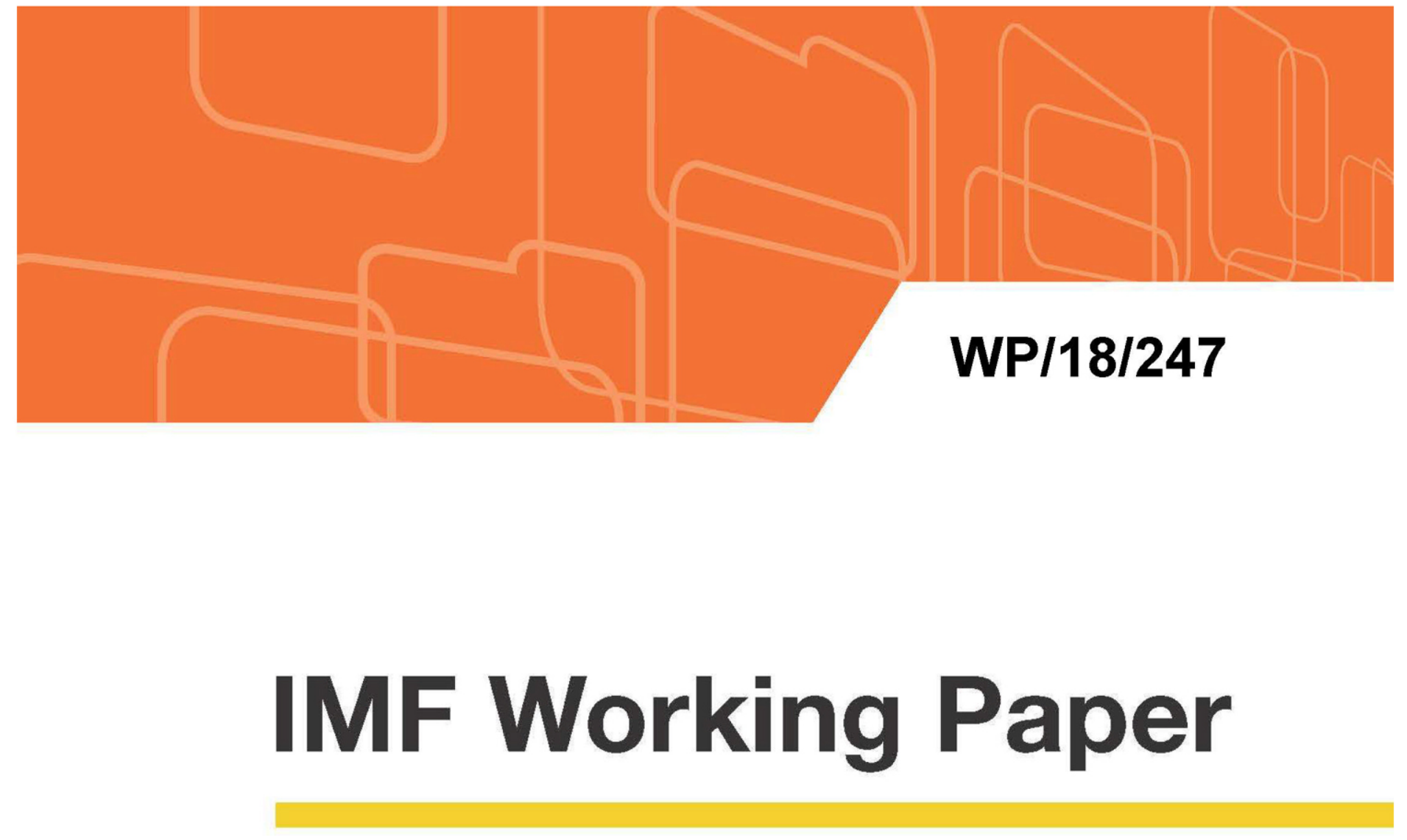

\title{
Brexit Referendum and Business Investment in the UK
}

by Lucyna Górnicka

IMF Working Papers describe research in progress by the author(s) and are published to elicit comments and to encourage debate. The views expressed in IMF Working Papers are those of the author(s) and do not necessarily represent the views of the IMF, its Executive Board, or IMF management. 


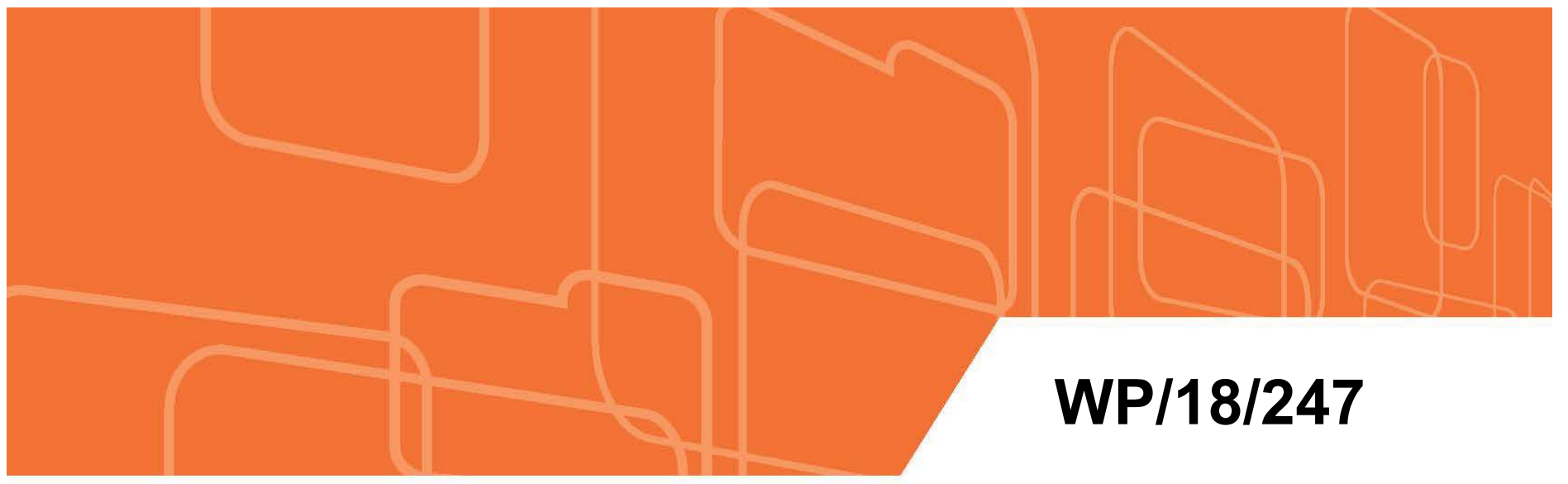

\section{IMF Working Paper}

\section{Brexit Referendum and Business Investment in the UK}

by Lucyna Górnicka

IMF Working Papers describe research in progress by the author(s) and are published to elicit comments and to encourage debate. The views expressed in IMF Working Papers are those of the author(s) and do not necessarily represent the views of the IMF, its Executive Board, or IMF management.

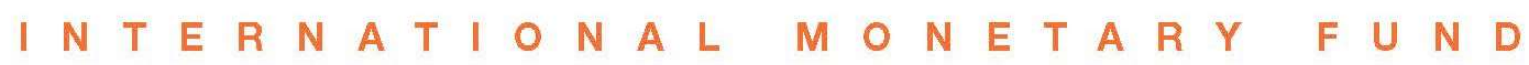




\title{
IMF Working Paper
}

European Department

\section{Brexit Referendum and Business Investment in the UK}

Prepared by Lucyna Górnicka ${ }^{1}$

Authorized for distribution by Dora Iakova

October 2018

\section{IMF Working Papers describe research in progress by the author(s) and are published to elicit comments and to encourage debate. The views expressed in IMF Working Papers are those of the author(s) and do not necessarily represent the views of the IMF, its Executive Board, or IMF management.}

\begin{abstract}
In this paper I apply firm-level analysis to examine how the Brexit process has affected business investment in the UK. An interaction term of potential trade costs after exiting the EU and a measure of firms' participation in global trade is used as a proxy for firm-level exposure to Brexit-related effects. The results suggest that potential trade costs have had a considerable and statistically significant negative impact on firm investment in the UK after the referendum. At the same time, the post-referendum sterling depreciation has likely contributed positively to investment expenditure by more foreign-oriented firms.
\end{abstract}

JEL Classification Numbers: D25, D80, F14

Keywords: Brexit referendum, firm investment, uncertainty, trade costs.

Author's E-Mail Address: lgornicka@imf.org

\footnotetext{
${ }^{1}$ International Monetary Fund, Monetary and Capital Markets Department. I would like to thank Lubai Yang for excellent assistance with data, Dora Iakova, Nicolas Arregui, Jack Chen, Raphael Espinoza, Mico Mrkaic, Tigran Poghosyan and Phillipe Wingender (all IMF) and the Staff at the HM Treasury and the Bank of England for useful comments.
} 


\section{INTRODUCTION}

After increasing quickly between 2011-2015, investment spending by the business sectorwhich accounts for roughly 50 percent of total investment in the $\mathrm{UK}^{2}$ - has slowed significantly in recent years. The y-o-y growth in business investment has averaged only 0.9 percent per quarter since 2016, half the rate that applied before the global financial crisis. Business investment growth is weak also in comparison to other advanced economies.

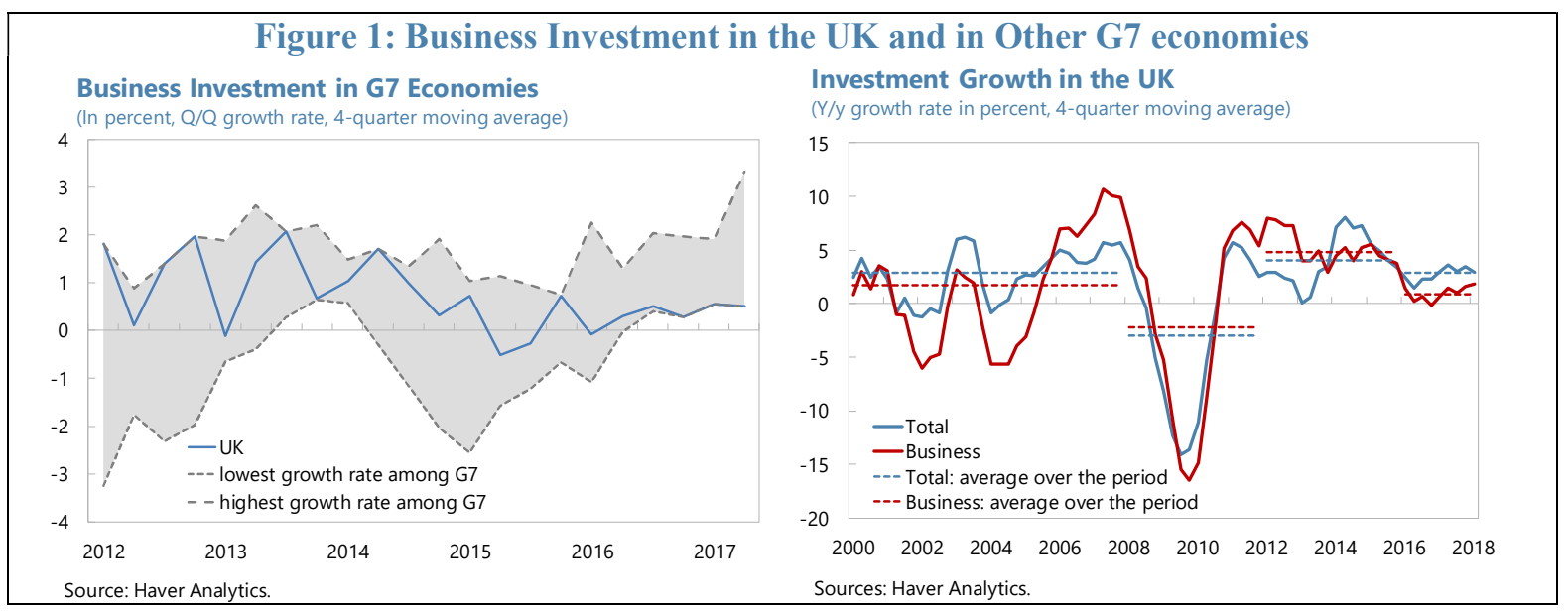

Several factors have potentially contributed to business investment underperformance. First, over the last two years output growth in the UK economy slowed too, suggesting that the weakening of business investment could be simply a result of more moderate GDP growth rates. Another proposed explanation is the uncertainty over the future business environment, created by the Brexit referendum. The economic literature (e.g. Bernanke 1983, Bloom et al. 2007) suggests that by increasing the value to firms of waiting, higher uncertainty depresses current investment. The 2016 referendum would also slow investment if it led firms to expect a worsening of the business environment after exiting the EU, prompting them to begin reducing investment immediately.

In this paper I examine whether the Brexit process has indeed affected business investment in the UK. First, I apply the Bean (1981) methodology to verify the extent to which fundamental factors, such as GDP performance and cost of capital, explain the recent business investment slowdown. The results indicate that cumulative business investment over the period 2016Q1-2018Q1 significantly underperformed relative to that predicted by the model (by 5.5 percent in real terms), even taking into account the impact of Brexit on economic growth. The impact of Brexit on investment is even larger if one recognizes that its impact on output growth has also depressed private investment: using a counterfactual GDP growth path consistent with a "no referendum" scenario suggests that absent the GDP slowdown, business investment would have been further 1.1 percentage point (i.e. 6.6 percent in total) higher than it was.

${ }^{2}$ In the UK, investment by public corporations is included in business investment, but public corporations' share in total business investment has been below 4 percent for most of the time in the last 20 years. Over the last 5 years, it has been oscillating marginally around 3 percent. 
The main contribution of the paper is to test the link between the Brexit process and business investment in a continuous-treatment difference-in-difference framework, applied to firmlevel data. An advantage of the proposed identification strategy is that it does not require estimating uncertainty, which is a difficult task.

The potential trade costs under a "no deal" scenario, i.e. trade costs in the case when there is no new trade agreement between the UK and the EU after the UK exits the block, are used as a proxy for firms' exposure to Brexit-related effects. Looking at an individual firm, higher potential future trade costs should imply more pessimistic expectations about the future business environment, as well as increased importance of Brexit-related uncertainty. Because the impact of potential increases in trade costs on a firm's investment decisions will vary depending on its exposure to international trade, the trade costs estimates are interacted with the share of foreign sales in the firm's total sales to obtain a firm-level measure of exposure. Post-referendum capital expenditure is estimated as a function of this interaction term, and a range of control variables. The results suggest that potential trade costs have had a considerable, and statistically significant, negative impact on firm investment in the UK after the referendum. At the same time, the post-referendum sterling depreciation has likely contributed positively to investment by more foreign-oriented firms.

The rest of this paper is organized as follows. Section II presents related literature. In Section III the link between aggregate business investment and fundamental factors is analyzed. In Section IV the empirical approach to analyzing the impact of Brexit and investment is discussed, and results of the firm-level analysis are presented. Section V concludes.

\section{RELATED LITERATURE}

This paper contributes to a growing literature on the impact of switches in the trade policy regime on firm behavior. Handley and Limão $(2015,2017)$ study the link between trade policy uncertainty and firm exports. Handley and Limao (2015) find that a reduction in uncertainty about the trade regime following Portugal's entry to the European Community in 1986 contributed considerably to the observed increase in exports activity by Portuguese firms.

The paper is closest in spirit to Crowley, Exton and Han (2018), who apply the Handley and Limão (2017) methodology to study the impact of Brexit on UK exports. Using data on UK firms' export transactions, they estimate that new entries into exporting new products to the EU by the UK firms would have been over 5 percent higher in 2016 absent increased trade policy uncertainty after the June 2016 referendum. Similar to this paper, they also use differentiation in trade costs under a "no deal" scenario to identify firms' exposure to Brexitrelated effects.

I also draw on the literature devoted to measuring the impact of uncertainty on firms' investment decisions (Bernanke 1983, Bloom et al. 2007, Bloom 2009, Gilchrist et al. 2014). Using data on UK manufacturing companies, Bloom et al. (2007) find that firms subject to greater uncertainty are more cautious in their investment decisions. Focusing on macroeconomic uncertainty, Redl (2017) finds that effects of uncertainty shocks in the UK 
depend on the source of the shocks, with events associated with political uncertainty showing a greater response of GDP to macroeconomic uncertainty. Also using UK data, Smietanka et al. (2018) finds that a rise in macroeconomic uncertainty leads firms to adjust their payout policies to secure additional cash against future risky cash flows. Melolinna et al. (2018) construct firm-specific measures of uncertainty from UK survey data, and show that uncertainty was a stronger driver of firm investment decisions than the user cost of capital over the last 20 years, particularly so after the global financial crisis (GFC).

Finally, the empirical approach to testing the link between the Brexit process and firm investment decisions employs the difference-in-difference methodology (Ashenfelter 1978, Ashenfelter and Card 1985). Through double differencing along time and between observations, this method aims to remove any biases between groups of observations that differ in their exposure to a policy or a treatment, that could be a result of permanent differences between those groups or a result of time trends unrelated to policy or treatment exposure. Imbens and Wooldridge (2009) present an overview of various difference-indifference applications.

\section{FUndaMental DETERMINANTS OF BUSINESS INVESTMENT IN THE UK}

The UK economy has slowed in recent years, despite stronger global growth. GDP growth fell from an average of 2.5 percent between 2013-2015 to 1.8 percent in 2016 and 1.7 percent in 2017. This is also much lower than the 2.8 percent averaged annually between 2000 and 2007.

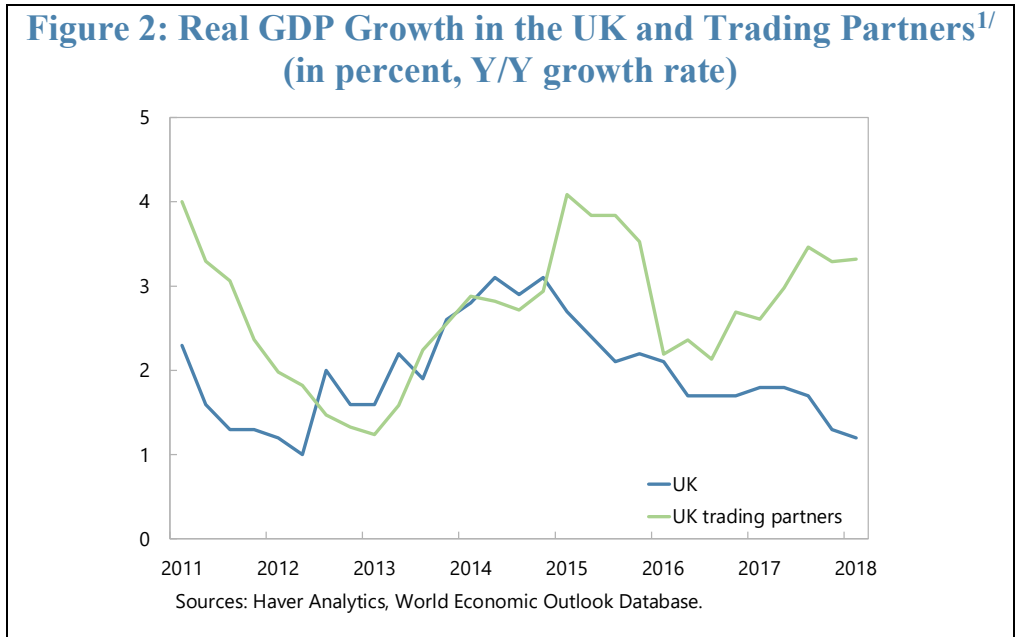

Can moderation of GDP growth fully account for the observed slowdown in business investment? To test this hypothesis, I use the Bean (1981) model of business investment, where investment growth $\Delta i$ is explained by lagged real GDP growth $\Delta y$, user cost of capital $u$, and difference between lagged investment and GDP levels $i-y$. 
Formally,

$$
\Delta_{k} i=\alpha+\gamma_{1} \Delta_{k} y_{t-i}+\gamma_{2} u_{t-i}+\gamma_{3} \Delta_{k} u_{t-i}+\gamma_{4}\left(i_{t-i}-y_{t-i-j}\right)+\epsilon_{t}
$$

where $i, j$, and $k$ are lag indices. The difference between the investment level and lagged GDP captures the idea that, at least in the long term, business investment should always return to its long-run equilibrium. Thus, a large increase in the investment to GDP ratio today should imply its decline at some point in the future, and the coefficient $\gamma_{4}$ in equation (1) should have a negative sign.

The literature on business investment offers several alternative specifications to equation (1). For example, IMF (2015) uses the accelerator model of Jorgenson and Siebert (1986) and Oliner et al. (1995) to investigate weak business investment during the GFC. Allard-Prigent et al. (2002) and Harrison et al. (2005) propose different versions of an error-correction model to capture dynamics of business investment both in the short and in the long term. However, both these approaches require the use of the net stock of capital to construct the dependent variable - which is difficult for the purposes of this paper due to poor quality of capital stock data in the UK. ${ }^{3}$ Thus, the Bean (1981) specification is preferred.

The model is estimated over the period 2000Q1-2015Q4. The user cost of capital is proxied by the sum of the real interest rate on 10-year Treasury bonds and the depreciation rate, with the latter derived from the annual series on capital stock and investment, and interpolated via a cubic spline into quarterly values. Following Bean (1981), I set $k=4$ and $j=5$, while the lag $i$ is chosen to maximize the fit of the model.

Table 1. Fundamental Drivers of Business Investment in the UK

Dependent variable: $y / y$ business investment growth

\begin{tabular}{lc}
$\mathrm{y} / \mathrm{y}$ GDP growth & $1.81 * * *$ \\
$\mathrm{y} / \mathrm{y}$ GDP growth, lag 4 & $1.77 * * *$ \\
log of user cost of capital, lag 9 & $-0.16^{* * *}$ \\
$\mathrm{y} / \mathrm{y}$ growth of user cost of capital, lag 5 & $-0.05^{*}$ \\
log of business investment to GDP(-5), lag 4 & $-0.67 * * *$ \\
constant & $-1.34 * * *$ \\
observations & 60 \\
R-squared & 0.74 \\
\hline robust standard errors, & \\
pval: $* * * \mathrm{p}<0.01, * * \mathrm{p}<0.05, * \mathrm{p}<0.1$ &
\end{tabular}

Notes: All variables are in log terms. The dependent variable is growth of business investment over the same quarter in previous year. All data comes from the Haver Analytics and the ONS.

\footnotetext{
${ }^{3}$ An accelerator model estimated using the UK data on total investment and total capital stock yields poor fit compared to other countries (e.g. the US), while none of explanatory variables is significant in a regression of business investment.
} 
Table 1 shows the results of the baseline regression. All coefficients of key explanatory variables are statistically significant and of expected signs. The fit is relatively high over the sample period, but the model performs poorly in capturing more abrupt swings in business investments before the GFC (Figure 3). Nevertheless, in the post-GFC period the model seems to capture the investment dynamics quite well.

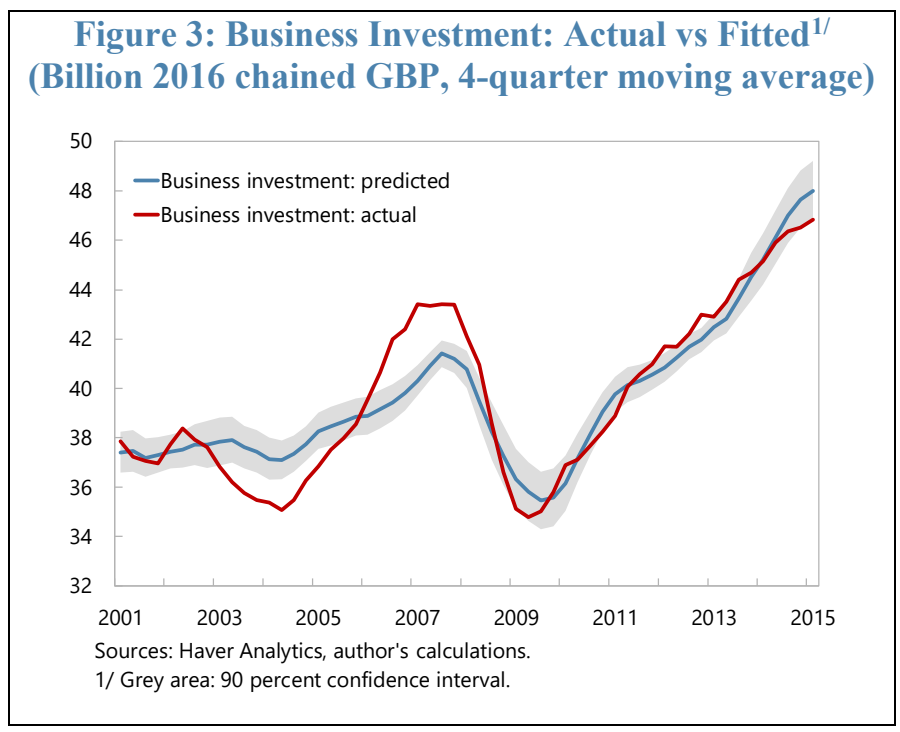

To quantify the impact of fundamental factors on business investment in the last two years, the estimates from Table 1 are used to make an out-of-sample forecast of business investment for 2016Q1-2018Q1, conditional on the realized paths of GDP and the user cost of capital. The results suggest that cumulative real business investment in the 9 quarters since the start of 2016 was 5.5 percent lower than implied by macroeconomic fundamentals (Figure 4). This is close to the estimate of nominal business investment underperformance of 3-4 percent by the $\mathrm{BoE}(2018){ }^{4}$

To verify the quality of the out-of-sample forecast for 2016Q1-2018Q1, the right-hand chart in Figure 4 compares the 8-period-ahead in-sample forecasts computed using equation (1) with the realized investment since 2007 . The in-sample forecasts seem to predict actual investment relatively well up until 2015 , when the two series start to diverge considerably, consistent with the hypothesis that special factors - not captured by the model - have weighed on business investment in the most recent years.

\footnotetext{
${ }^{4} \mathrm{BoE}$ (2018) notes that the effect in real terms would likely be higher. The BoE (2018) estimate refers to the 1 year between 2016Q2 and 2017Q2: an estimate from model (1) for the same period yields a value of 5 percent in real terms. A forthcoming work by Paul Mizen and coauthors estimates the impact of Brexit-related uncertainty on firm investment at around 5 percent (presentation at the Developing and Using Business Expectations Data Conference, October 25-26, 2018, University of Chicago, Booth School of Business).
} 
Finally, the results of the forecast analysis are robust to i) excluding the current period GDP growth from equation (1), ii) including a lagged level of business investment, iii) estimating the model until 2014Q4 and making the projection starting in Q1 2015.

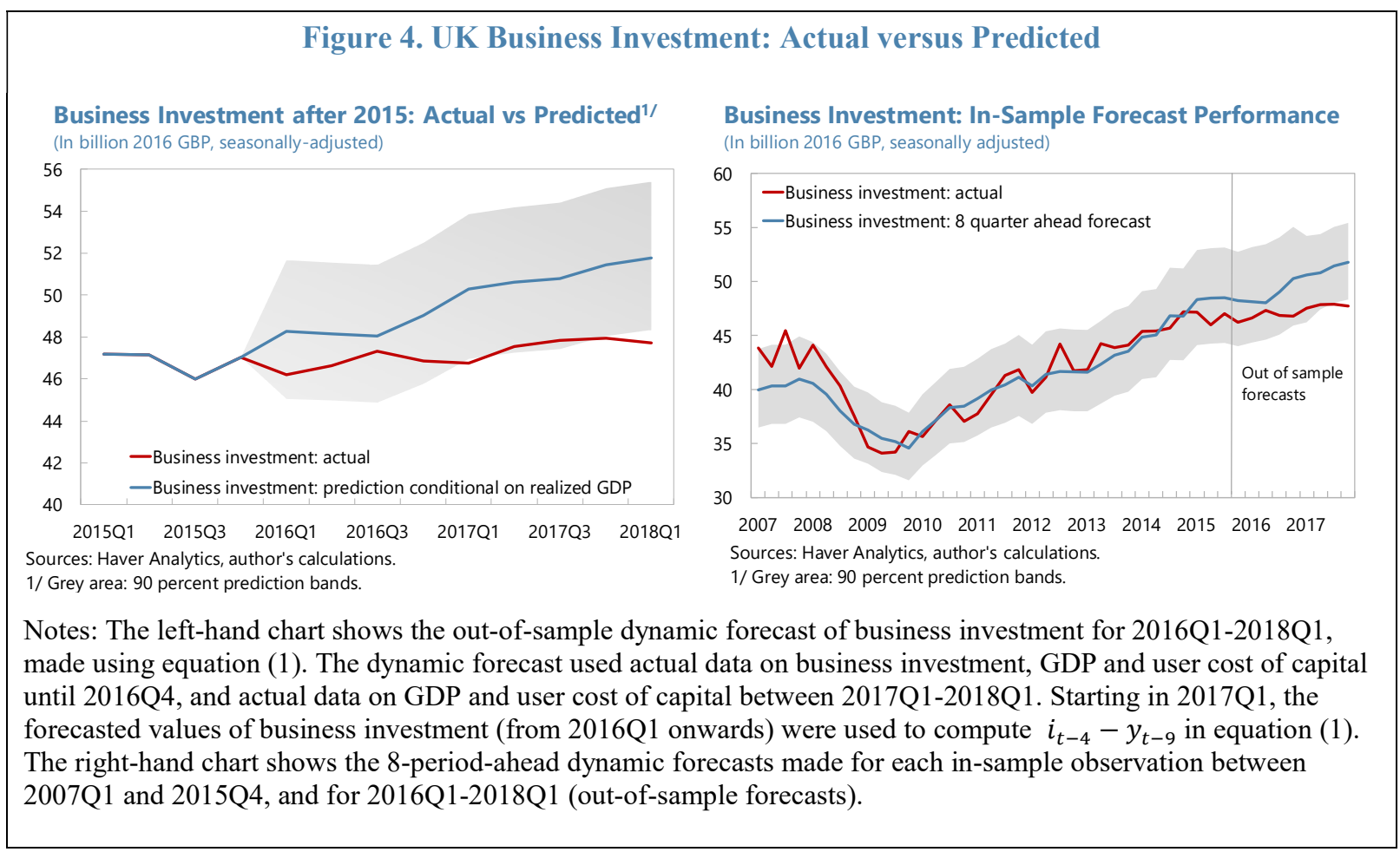

The 5.5 percent gap between predicted and observed values is an estimate of business investment underperformance attributable to factors outside the model (1). How does this compare to the impact that slower GDP growth has had on business investment? To get a sense of relative importance of special factors versus GDP, I conduct a quick exercise. First, I estimate a "counterfactual" UK GDP path after the June 2016 referendum using the synthetic control method in Abadie and Gardeazabal (2003) and in Born et al. (2017). I then make another business investment forecast for 2016Q1-2018Q1, conditional on the new GDP growth series.

The average estimate of the difference between the actual GDP and the counterfactual GDP path from the synthetic control method is -1.7 percent as of 2018Q1 (in real terms). ${ }^{5}$ Applying the counterfactual GDP growth path to the conditional forecast of business investment yields a total "loss" of 6.6 percent since end-2015. Thus, the ad-hoc exercise suggests that business investment would have been 1.1 percent higher absent the GDP slowdown, and 5.5 percent higher if "special factors" were not present (Figure 5).

\footnotetext{
${ }^{5}$ The -1.7 percent is an average across 7 alternative model specifications (see Figure 5 for details), measured in terms of 2016Q2 GDP. This is similar to Born et al. (2017) who estimate a GDP "loss" due to the Brexit referendum of 1.3 percent between 2016Q1 and 2017Q3.
} 
Figure 5. UK Business Investment: Forecast Conditional on Counterfactual GDP
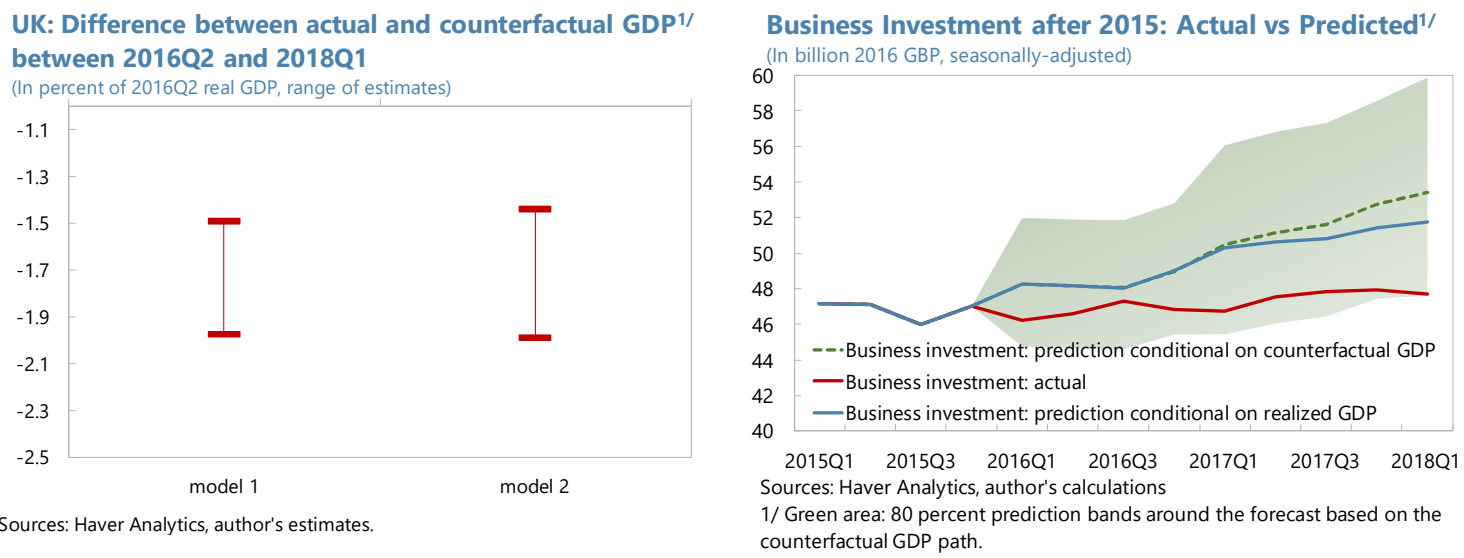

Notes: The left-hand chart shows a range of estimates of the cumulative difference between actual real UK GDP and the counterfactual real GDP series in the period 2016Q3-2018Q1. Counterfactual GDP is estimated using the methodology in Abadie and Gardeazabal (2003) and Born et al. (2017), where UK GDP is regressed on GDP series of a sample of OECD economies (model 1), while additionally controlling for differences in structural characteristics between the UK economy and other countries (model 2). The right-hand chart shows the out-ofsample dynamic forecast of business investment for 2016Q1-2018Q1, made using equation (1) and conditional on the counterfactual GDP path. The counterfactual GDP path was constructed using the average estimate from models 1 and 2 in left-hand chart, i.e. -1.7 percent. Real GDP series were increased by the same amount in each quarter between 2016Q3 and 2018Q1, so that the distance from the actual GDP reaches 1.7 percent (in terms of 2016Q2 GDP) in 2018Q1. The prediction bands in the chart take into account the uncertainty around both the counterfactual GDP estimate and the forecasts made using model (1).

A commonly given explanation for sluggish business investment growth is uncertainty related to the Brexit process ${ }^{6}$ : It is a well-established result that heightened uncertainty depresses current investment by increasing the value of waiting to firms. One way to test whether this has indeed been the case is to include uncertainty as an additional explanatory variable in equation (1). However, the measurement of uncertainty is a difficult task. In particular, recent literature argues that a good measure of uncertainty should be forwardlooking and stripped of the forecastable part (Jurado et al. 2015). Mindful of those concerns, I use four measures of uncertainty to augment model (1): Economic Policy Uncertainty Index (EPU) by Baker et al. (2016), London Stock Exchange Volatility Index, and two alternative macroeconomic policy uncertainty indices constructed using Jurado et al. (2015) methodology (see Appendix I for details). EPU is a weighted average of three components: i) an index based on the newspaper coverage of policy-related economic uncertainty, ii) a number of tax provisions set to expire in coming years, iii) a variance of forecasts among economic forecasters. The two macroeconomic uncertainty measures are derived as a weighted average of variances of prediction errors for a range of macroeconomic and financial time series, thus directly addressing the issue of non-forecastability.

\footnotetext{
${ }^{6}$ The uncertainty narrative was likely not the only factor at play in 2016 . For example, it has been argued that following the oil price crash in late 2015, the oil and mining sector has weighed on business investment in 2016. However, as production investment is not only determined by the oil price, it should suffer from uncertainty too.
} 
Table 2 shows the results of adding the uncertainty measures to equation (1). The EPU index (at lag 4) and the stock market volatility (at lag 8) are statistically significant (and have the expected negative sign), while the two measures of macroeconomic uncertainty are not. This is consistent with Redl (2017), who finds that events associated with political uncertainty show a greater response of GDP. Looking at the forecast of business investment in 2016Q12018Q1, the difference between the predicted and actual business investment falls from 5.5 to 4.7 percent when EPU is added to the model. ${ }^{7}$

Taken at face value, this suggest that there have been channels or Brexit-related factors other than uncertainty that affected investment over the last two years. However, it must be noted that the coefficient on uncertainty measures in equation (1) does not necessarily reflect the full impact of uncertainty — which could weaken business investment e.g. through its impact on GDP growth in consecutive quarters as well. Moreover, the results should be interpreted with caution given the difficulties related to measuring uncertainty. Also for these reasons, in the next section I turn to firm-level data to study the link between the Brexit process and business investment at the decision-maker level.

Table 2. Drivers of Business Investment in the UK: Augmented Model

Dependent variable: $y / y$ business investment growth

\begin{tabular}{|c|c|c|c|c|}
\hline & (1) & (2) & (4) & (5) \\
\hline y/y GDP growth & $1.74 * * *$ & $1.80 * * *$ & $1.76 * * *$ & $1.80 * * *$ \\
\hline y/y GDP growth, lag 4 & $1.73 * * *$ & $1.33 * * *$ & $1.80 * * *$ & $1.76 * * *$ \\
\hline log of user cost of capital, lag 9 & $-0.21 * * *$ & $-0.15 * * *$ & $-0.17 * * *$ & $-0.17 * * *$ \\
\hline $\mathrm{y} / \mathrm{y}$ growth of user cost of capital, lag 5 & $-0.08 * * *$ & $-0.05 *$ & $-0.06 *$ & $-0.06^{*}$ \\
\hline $\log$ of business investment to $\operatorname{GDP}(-5)$, lag 4 & $-0.71 * * *$ & $-0.69 * * *$ & $-0.71 * * *$ & $-0.71 * * *$ \\
\hline $\log$ of EPU, lag 4 & $-0.02 *$ & & & \\
\hline $\log$ of stock market volatility, lag 8 & & $-0.05 * * *$ & & \\
\hline macroeconomic uncertainty 1 , lag 4 & & & -0.01 & \\
\hline macroeconomic uncertainty 2 , lag 4 & & & & 0.002 \\
\hline constant & $-1.25 * * *$ & $-1.26 * * *$ & $-1.41 * * *$ & $-1.41 * * *$ \\
\hline Observations & 60 & 58 & 58 & 56 \\
\hline R-squared & 0.75 & 0.78 & 0.74 & 0.74 \\
\hline
\end{tabular}

robust standard errors

pval: $* * * \mathrm{p}<0.01, * * \mathrm{p}<0.05, * \mathrm{p}<0.1$

Notes: The dependent variable is growth of business investment over the same quarter previous year. All data comes from the Haver Analytics and the ONS. The lags on the uncertainty measures were chosen to maximize the model fit. The stock market volatility is the London Stock Exchange Volatility Index. The two measures of macroeconomic uncertainty in specifications (3)-(4) are derived using Jurado et al. (2015) methodology—see Appendix I for details.

\footnotetext{
7 Two other variables that were also added to equation (1): exchange rate, relative price of investment. Only the exchange rate was statistically significant at lag 8, but its addition did not result in reducing the post-2015 difference between actual and model-implied business investment.
} 


\section{BReXit AND Business InVESTMEnt: A FiRM-LeVEl AnAlysis}

The referendum in June 2016 started the process of the UK's exit from the European Union. There is convincing evidence that the decision to leave the EU has also affected the UK economy. Sterling depreciated sharply after the referendum, pushing up inflation and depressing private consumption, while GDP growth moderated in 2017 despite significant monetary policy stimulus by the Bank of England and strong trading partner growth. As already mentioned, in the context of business investment, the uncertainty related to future trading arrangements with the EU has been broadly seen as the main impediment.

Yet, there are arguably several channels through which the Brexit process could have affected business investment. Following Crowley, Exton and Han (2018), one can think about the Brexit vote as an unexpected switch in the trade policy regime, understood as a change in the level and the likelihood of the UK's future trade costs schedule. The referendum increased the uncertainty faced by the firms as it involved a switch from a state of certainty about the trade arrangements to a state where multiple trade regimes are possible in the future.

At the same time, it has been broadly feared that any future trade regime will involve trading costs higher than currently faced by the UK companies - i.e. that the expected future trade costs are higher than before. ${ }^{8}$ If the UK businesses indeed expect a worsening of their future business environment following the exit from the EU, they could have started adjusting investment to the new equilibrium already now. Finally, the sterling depreciation triggered by the referendum has likely benefited profits of firms with foreign sales and revenues, which could have translated into higher investment by those more foreign-oriented companies.

Given the above, it is reasonable to expect that the exposure to Brexit-related effects for an individual firm will depend both on the firm's participation in foreign trade, and on the trade costs the firm can potentially face in the future. In particular, the uncertainty about the future trade arrangements will also matter more for firms with bigger presence in global markets and with higher potential trade costs ahead.

In the empirical analysis that follows, I use this differentiation in firm-level exposure to foreign trade and to future trade costs to identify the impact of the Brexit process on business investment. An advantage of this identification strategy is that it does not require estimating uncertainty.

Formally, the post-referendum capital expenditure $i n v_{i}$ of a firm $i$ is specified as a function of a range of control variables $\boldsymbol{X}_{i}$, a share of foreign sales in total firm sales $F S T S_{i}$, and an interaction term between $F S T S_{i}$ and potential trade costs $T C_{i}$ faced by the firm after exiting the EU:

\footnotetext{
${ }^{8}$ The EU is the largest trading partner for the UK, and leaving the EU implies higher costs of trading (at bestonly marginally higher) with its member states. The UK government's own provisional analysis (EU Exit Analysis, Cross Whitehall Briefing 2018) has indicated that new trade deals with third countries are unlikely to counterweight the loss of access to the EU market.
} 


$$
\operatorname{inv}_{i}=\alpha+\beta \boldsymbol{X}_{i}+\gamma F S T S_{i}+\delta\left(F S T S_{i} \times T C_{i}\right)+\varepsilon_{i} .
$$

The expected sign of the coefficient $\gamma$ on the stand-alone term $F S T S_{i}$ is positive: sterling depreciation and stronger global growth in the post-referendum period should induce a firm with a higher share of foreign sales to invest more. The interaction term $F S T S_{i} \times T C_{i}$ should capture the two other two channels through which the Brexit process could affect firm investment, i.e. an increase in the expected future trade costs and heightened uncertainty about them, with the sign of the coefficient $\delta$ negative.

Equation (2) is a form of a difference-in-difference (diff-in-diff) specification applied to panel data. ${ }^{9}$ The dependent variable — investment—is simply a difference between the postand pre-referendum fixed assets of a firm, and pre-referendum fixed assets are one of the control variables in the vector $\mathbf{X}_{\mathbf{i}}$. An implicit assumption is that of unconfoundedness, i.e. that controlling for pre-referendum differences in firm characteristics (through $\mathrm{X}_{\mathrm{i}}$ ) removes all biases in comparisons between firms with different exposure to Brexit-related effects. Given that the result of the Brexit referendum was broadly unexpected, the self-selection into the treatment is very unlikely. As the control variables we use a wide range of variables that are commonly applied in the literature on firm investment (see below), to ensure the vector of controls is rich enough to ensure unconfoundedness.

\begin{tabular}{|c|c|c|c|}
\hline \multirow{2}{*}{ Sector } & \multicolumn{3}{|c|}{ Cost of trading under WTO rules } \\
\hline & Tariffs & Non-tariff costs & Total \\
\hline Agriculture, forestry and fishing & 5.9 & 18.0 & 23.9 \\
\hline Mining and quarrying & 0.0 & 14.7 & 14.7 \\
\hline Food, drinks and tobacco & 7.3 & 17.0 & 24.3 \\
\hline Textiles, clothing, leather and footwear & 9.6 & 19.2 & 28.8 \\
\hline Solid fuels and oil refining & 2.7 & 14.7 & 17.4 \\
\hline Chemicals and man-made fibers & 2.7 & 13.0 & 15.7 \\
\hline Metals and metal goods & 2.1 & 9.0 & 11.0 \\
\hline Engineering and vehicles & 4.0 & 13.3 & 17.3 \\
\hline Electricity, gas and water & . & 6.0 & 6.0 \\
\hline Construction & . & 0.0 & 0.0 \\
\hline Distribution services & . & 21.0 & 21.0 \\
\hline Transport and storage & . & 14.1 & 14.1 \\
\hline Hotels and restaurants & . & 14.7 & 14.7 \\
\hline Financial intermediation & . & 25.4 & 25.4 \\
\hline Real estate, renting and business & . & 14.8 & 14.8 \\
\hline Education & . & 17.0 & 17.0 \\
\hline Health and social work & . & 17.0 & 17.0 \\
\hline Other services & . & 17.0 & 17.0 \\
\hline
\end{tabular}

As a measure of potential trade costs after the exit from the EU, I use sector-level estimates from Berden et al. (2009) and Dhingra et al. (2016). These estimates (Table 3) correspond to

\footnotetext{
${ }^{9}$ See Section 6.5 in Imbens and Wooldridge (2009) for a detailed discussion.
} 
a "no deal" scenario, whereby the UK leaves the EU without a new trade agreement, and the UK companies have to trade under WTO provisions. Trading under WTO rules is arguably an extreme scenario, but given uncertainty about the outcome of negotiations, this scenario is likely also taken into account by firms, and thus correlated with their expectations of future trade costs, as well as with the importance of Brexit-related uncertainty for an individual firm.

I use balance sheet data for UK-listed non-financial companies from Datastream. ${ }^{10}$ For comparison purposes, I focus on companies ending their fiscal year in December-March. Together with eliminating firms with missing data, clear outliers and firms in FTSE100 (see explanation below), this leaves around 250-350 firms in the sample, depending on the choice of controls and further removal of outliers.

As controls I use a range of variables usually applied in the analysis of firm investment: indicators of profitability and available liquid funds (EBITDA, ROA, ROE, working capital), a measure of efficiency of investment in generating revenues (ratio of sales to fixed assets), firm leverage and cost of capital (total debt to common equity or total assets, interest paid on debt outstanding), market to book ratio (as a proxy of Tobin's q), stock price volatility. All control variables are as of end-2015, and the dependent variable is capital expenditure in the six quarters between 2016Q1 and 2017Q2, scaled by fixed assets at end-2015. ${ }^{11}$

Table 4 summarizes the results. The negative and statistically significant coefficient on the interaction term $F S T S \times T C$ suggests that potential future trade costs have had a negative impact on firm investment in the UK after the referendum. At the same time, the positive and statistically significant coefficient on FSTS is consistent with the post-referendum sterling depreciation and stronger global growth contributing positively to investment expenditure by more foreign-oriented firms.

Column 1 in Table 4 shows the baseline specification. The results are robust to including standalone WTO trade costs (column 2) and a measure of cost of capital (column 3). ${ }^{12}$ In column 4, I use investment in 2016 as the dependent variable. The results remain significant also when i) using alternative measures of profitability (ROE, ROA) and cash available (working capital), ii) including stock price volatility, iii) including dividend payouts per share, iv) pooling observations from both the post-referendum and the pre-referendum period and estimating equation (2) as a 2-period panel regression (Appendix II). ${ }^{13}$

The share of foreign sales in total sales is used as a proxy for a firm's exposure to foreign trade. Unfortunately, this variable does not clearly distinguish between exports and revenue generated by foreign subsidiaries of a firm, including through own production. ${ }^{14}$ As the UKlisted companies potentially include large multinationals with businesses all around the

\footnotetext{
${ }^{10}$ Alternative data sources, such as Orbis were considered, but at the time of analysis the Orbis had very few firm observations for the year 2017.

${ }^{11}$ As of July 2018, data for 2017Q4 was available for only few companies.

12 The interest paid on debt is not included in the baseline specification as this reduces the size of the sample by over 40 firms.

13 This is done to increase the number of observations in the sample.

${ }^{14}$ Data on exports revenue is available for few firms only.
} 
globe, in column 5 I exclude firms with the share of foreign assets above 50 percent of total assets. Additionally, all regressions exclude FTSE100 firms. Ideally, this should leave in the sample only firms with most of their production - and location of business investment - in the UK.

A potential issue remains regarding whether the share of foreign sales in total firm's sales is a precise measure of firm's exposure to trade costs. Arguably, this does not include firms that rely to a large extent on imports of intermediate goods, while selling their products primarily in the UK. Unfortunately, due to data limitations I cannot properly control for this.

Table 4. Business Investment and Brexit Process: Firm-Level Analysis

Dependent variable: investment to fixed assets (in percent)

\begin{tabular}{lccccc}
\hline & $(1)$ & $(2)$ & $(3)$ & $(4)$ & $(5)$ \\
\hline & & & & & \\
Fixed assets to total assets & $-0.42^{* * *}$ & $-0.42^{* * *}$ & $-0.38^{* *}$ & $-0.27 * * *$ & $-0.43^{* * *}$ \\
EBITDA & 0.28 & 0.28 & 0.04 & 0.19 & $0.47^{*}$ \\
Sales to fixed assets & $0.002^{* * *}$ & $0.002^{* * *}$ & $0.002^{* * *}$ & $0.001^{* * *}$ & $0.002^{* * *}$ \\
Total assets, log & $-3.47^{*}$ & $-3.47^{*}$ & $-3.91^{*}$ & -1.38 & $-3.03^{* *}$ \\
Total debt to common equity & $-0.08^{*}$ & $-0.08^{*}$ & $-0.09 *$ & $-0.04 *$ & $-0.09^{*}$ \\
Market to book ratio & 0.0007 & 0.0006 & 0.01 & -0.0001 & -0.0009 \\
Foreign sales to total sales (FSTS) & $\mathbf{0 . 3 7 *}$ & $\mathbf{0 . 3 9 *}$ & $\mathbf{0 . 3 8}$ & $\mathbf{0 . 2 1 * *}$ & $\mathbf{0 . 3 9 *}$ \\
FSTS*WTO trade costs & $\mathbf{- 0 . 0 2 * *}$ & $\mathbf{- 0 . 0 2 * *}$ & $\mathbf{- 0 . 0 2 *}$ & $\mathbf{- 0 . 0 2 * *}$ & $\mathbf{- 0 . 0 2 * *}$ \\
WTO trade costs & & 0.18 & & & \\
Interest rate on debt & & & $-0.05^{* * *}$ & & \\
Constant & $78.80^{* * *}$ & $76.24 * *$ & $84.96^{* * *}$ & $42.24 * * *$ & $77.09 * * *$ \\
Sector dummies & YES & YES & YES & YES & YES \\
Observations & 270 & 270 & 227 & 281 & 225 \\
R-squared & 0.32 & 0.32 & 0.33 & 0.30 & 0.30 \\
\hline
\end{tabular}

Robust standard errors (clustered at sector level)

$* * * \mathrm{p}<0.01, * * \mathrm{p}<0.05, * \mathrm{p}<0.1$

Notes: The dependent variable is capital expenditure in 6 quarters between 2016Q1 and 2017Q2, in percent of end2015 fixed assets. Net book value of plants, machinery and equipment is used as a measure of fixed assets. All control variables are as of end-2015, and in percent terms unless otherwise specified. For the FSTS I use the average annual value between 2013-2015 to include also firms for which FSTS is reported only every few years. Specification (1) is the baseline specification, in version (2) I add standalone sectoral WTO costs. In model (3) the effective interest rate on outstanding debt is included, in model (4) the 2016 investment is used as the dependent variable. In specification (5) only firms with the share of foreign assets in total assets below 50 percent are included.

Finally, to make sure the variables of interest truly capture Brexit-related effects instead of reflecting e.g. omitted variables, I re-estimate equation (2) using data for years 2014 and 2015 but including the same FSTS and FSTS $\times$ TC variables as before. Consistent with expectations, the two terms cease to be statistically significant in the regressions of prereferendum investment.

In sum, the key finding that the anticipated Brexit-related trade effects have weighed on firm investment in the UK is very robust. Nevertheless, a few caveats apply when interpreting the results. First, while the interaction term $F S T S \times T C$ captures both the uncertainty and the expectations channels, it does not allow to identify which of them has played a more 
important role after the referendum. The findings in Section III, where various measures of uncertainty turned out to have weak impact on aggregate business investment, might suggest that the expectations channel has been more important. Yet, given the issues related to measuring uncertainty, the results from Section III should be interpreted with caution.

Secondly, the approach based on using differentiation in firm-level exposure to Brexit to identify its impact on investment does not fully capture the impact of the average change in uncertainty or expectations across all firms after the referendum. Finally, as the sample consists of listed companies only, it does not capture potential differentiation of Brexitrelated effects by the firm size. In terms of coverage, capital expenditure of firms in the sample used for regressions accounted for around 10 percent of total investment by private non-financial firms in 2016.

\section{Conclusions}

In this paper I examine the drivers of weak business investment in the UK after 2015. The analysis of aggregate business investment in the recent period suggests that factors other than macroeconomic fundamentals must have played a significant role, as investment has performed worse than can accounted for solely by the behavior of fundamentals.

To test the link between the Brexit process and business investment, I use firm-level data. In the analysis, an interaction term of potential trade costs after exiting the EU and a measure of firms' participation in global trade is used as a proxy for firm-level exposure to Brexit-related effects. The identification strategy does not require estimating uncertainty, which is a difficult task. At the same time, however, the above approach does not allow one to distinguish between alternative channels through which the Brexit process could affect firm investment.

The results suggest that potential trade costs have had a considerable, and statistically significant, negative impact on firm investment in the UK after the referendum. At the same time, however, the post-referendum sterling depreciation has likely contributed positively to investment expenditure by more foreign-oriented firms. 


\section{References}

Allard-Prigent, C., Audenis, C., Berger, K., Carnot, N., Duchene, S. and F. Pesin (2002), Modèle Econométrique de Simulation et d'Analyse Générale de l'Economie, French Ministry of Economy, Finance and Industry 2002.

Ashenfelter, O. (1978), Estimating the Effect of Training Programs on Earnings, Review of Economics and Statistics 6 (1), 47-57.

Ashenfelter, O. and D. Card (1985), Using the Longitudinal Structure of Earnings to Estimate the Effect of Training Programs, Review of Economics and Statistics, 67 (4), 64860 .

Baker, S. R., Bloom, N. and S. J. Davis (2015), Measuring Economic Policy Uncertainty, Technical Report, National Bureau of Economic Research.

Bank of England (2018), Inflation Report, February 2018.

Bean, C. B. (1981), An Econometric Model of Manufacturing Investment in the UK, The Economic Journal 91 (361), 106-121.

Berden, K., Francois, J., Tamminen, S., Thelle, M. and P. Wymenga (2009), Non-Tariff Measures in EU-US Trade and Investment - An Economic Analysis, Ecorys report prepared for the European Commission, Reference OJ 2007/S180219493.

Bernanke, B. (1983), Irreversibility, Uncertainty, and Cyclical Investment, Quarterly Journal of Economics, 98, 85-106.

Bloom, N. (2009), The Impact of Uncertainty Shocks, Econometrica, 77, 623-685.

Bloom, N., Bond, S. and J. van Reenen (2007), Uncertainty and Investment Dynamics, Review of Economic Studies, Vol. 74, pp. 391-415.

Crowley, M., Exton, O. and L. Han (2018), Renegotiation of Trade Agreements and Firm Exporting Decisions: Evidence from the Impact of Brexit on UK Exports, Cambridge-INET Working Paper Series No: 2018/10.

Dhingra, S., Ottaviano, G., Sampson T. and J. van Reenen (2016), The Consequences of Brexit for UK Trade and Living Standards, Centre for Economic Performance Brexit Analysis 02.

Gilchrist, S. and E. Zakrajsek (2007), Investment and the Cost of Capital, NBER Working Paper 13174.

Gilchrist, S., Sim, J. and E. Zakrajsek (2014), Uncertainty, Financial Frictions, and Investment Dynamics, NBER Working Paper 20038. 
Handley, K. and N. Limão (2015), Trade and Investment Under Policy Uncertainty: Theory and Evidence, American Economic Journal: Economic Policy 7, 189-222.

Handley, K. and N. Limão (2017), Policy Uncertainty, Trade, and Welfare: Theory and Evidence for China and the United States, American Economic Review 107, 2731-2783.

Harrison, R., Nikolov, K., Quinn, M., Ramsay, G., Scott, A. and R. Thomas (2005), The Bank of England Quarterly Model, Bank of England 2005.

Imbens, G. and J.M. Wooldridge (2009), Recent Developments in the Econometrics of Program Evaluation, Journal of Economic Literature 47 (1), 5-86.

Jorgenson, D. and C. Siebert (1968), A Comparison of Alternative Theories of Corporate Investment Behavior. American Economic Review 58 (September), 681-712.

Jurado, K., Ludvigson, S.C and S. Ng (2015), Measuring Uncertainty, American Economic Review 105 (3), 1177-1216.

Melolinna, M., Miller, H. and S. Tatomir (2018), Business Investment, Cost of Capital and Uncertainty in the United Kingdom - Evidence from Firm-Level Analysis, Bank of England Staff Working Paper 717.

Oliner, S., Rudebusch, G. and D. Sichel (1995), New and Old Models of Business Investment: A Comparison of Forecasting Performance, Journal of Money, Credit, and Banking 27 (3), 806-26.

International Monetary Fund (2015), Private Investment: What's the Holdup?, World Economic Outlook April 2015 (Chapter 4).

Redl, Ch. (2017), The Impact of Uncertainty Shocks in the United Kingdom, Bank of England Staff Working Paper 695.

Smietanka, P., Bloom, N. and P. Mizen (2018), Business investment, cash holding and uncertainty since the Great Financial Crisis, Bank of England Staff Working Paper 753. 


\section{Appendix I. Measuring Macroeconomic Uncertainty}

Jurado et al. (2015) define h-period ahead uncertainty in the variable $y_{t}$ as the conditional volatility of the purely unforecastable component of $y_{t}$ :

$$
U_{t}^{y}(h)=\sqrt{E\left[\left(y_{t+h}-E\left[y_{t+h} \mid I_{t}\right]\right)^{2} \mid I_{t}\right]},
$$

where $I_{t}$ stands for the information set available to forecasters at period $t$. A macroeconomic uncertainty index is then simply an average of uncertainty measures of individual series $y$.

Jurado et al. (2015) estimate a macroeconomic uncertainty index in a three-step procedure. First, they apply a principal component regression to a range of macroeconomic and financial variables and extract a subset of principal components (PCs). In the second step, for each of the macro variables, a VAR consisting of that variable and the principal components from step one is estimated. The residuals from the VAR are used to calculate the uncertainty index in (A1). Finally, the aggregate macroeconomic uncertainty index is derived as an average of the individual uncertainty series.

I construct two versions of a macroeconomic uncertainty index for the UK based on 29 variables in Table A1. The data is quarterly and the sample goes from 2000Q1 to 2018Q1.

\begin{tabular}{|l|l|}
\hline \multicolumn{2}{|c|}{ Table A1: Variables Used to Construct the Macroeconomic Uncertainty Index } \\
Group & $\begin{array}{l}\text { Variables } \\
\text { household real disposable income, industrial } \\
\text { production index } \\
\text { employment total, employment in the private sector, } \\
\text { employment in manufacturing, unemployment rate, } \\
\text { total weekly hours worked, unit labor costs } \\
\text { new housing completions } \\
\text { retail sales, turnover in manufacturing, turnover in } \\
\text { services } \\
\text { lending to the private sector, lending to individuals, } \\
\text { household debt to income ratio, M1 money stock, M2 } \\
\text { money stock } \\
\text { interest rates: BoE bank rate, Libor, 1-year Treasury } \\
\text { bonds, 5-year Treasury bonds, 10-year Treasury } \\
\text { bonds; exchange rate against USD, FTSE All-share } \\
\text { index } \\
\text { Consumption and orders } \\
\text { consumer price index, consumer price index: } \\
\text { services, consumer price index: durable goods, oil } \\
\text { price, producer price index. }\end{array}$ \\
Bond and exchange rates, stock market & \\
Prices &
\end{tabular}

Three first three PCs and a square of the first principal component are used in the VAR. I follow Jurado et al. (2015) and add PCs for the squared macroeconomic variables to the VAR, when constructing macroeconomic index 1 . The number of lags in the VAR is then set to $\mathrm{L}=2$. For the macroeconomic index 2, I remove the PCs for the squared variables, but extend the number of lags to $\mathrm{L}=4$. Chart below plots the computed macroeconomic uncertainty indices against the EPU index. 


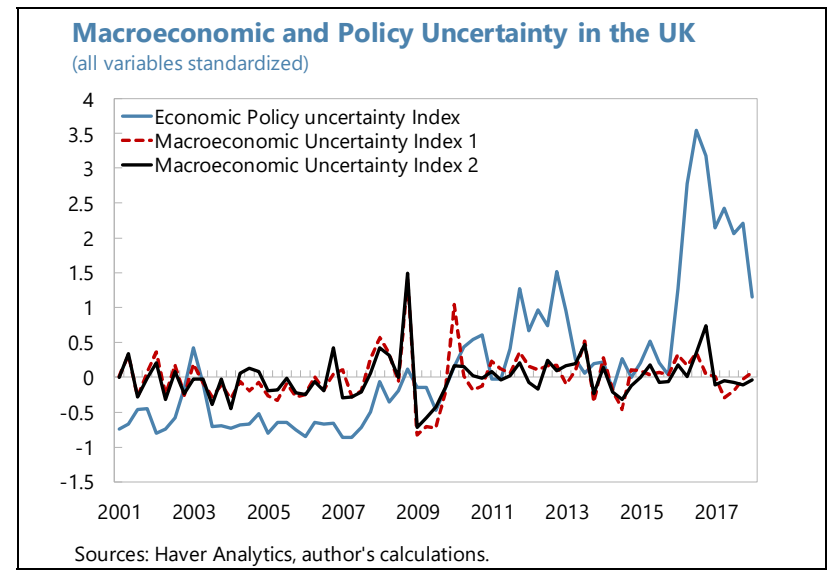




\section{Appendix II. Firm-level Analysis: Robustness}

To increase the number of observations in the firm-level analysis, I set up a as a 2-period panel regression:

$$
\begin{aligned}
& i n v_{i, t}=\alpha+\beta \boldsymbol{X}_{i, t}+\sigma I_{\text {post-ref }}+\gamma_{1} \text { FSTS }_{i}+\gamma_{2}\left(\text { FSTS }_{i} \times I_{\text {post-ref }}\right)+\delta\left(\text { FSTS }_{i} \times T C_{i} \times\right. \\
& \left.I_{\text {post-ref }}\right)+\varepsilon_{i},
\end{aligned}
$$

where $t=0$ for the pre-referendum period (2014Q1-2015Q2) and $t=1$ for the post-referendum period (2016Q1-2017Q2). $I_{\text {post-ref }}$ is an indicator equal to 1 when $t=1$. Control variables $\boldsymbol{X}_{i, t}$ are as of 2014Q2 when $t=0$ and as of 2015Q4 when $t=1$. I allow the foreign sales term FSTS to have a different impact on firm investment in the two periods by adding the interaction term FSTS $_{i} \times I_{\text {post-ref }}$. Table A2 presents the results.

Table A2: Business Investment and Brexit Process: 2-Period Panel Regression

Dependent variable: investment to fixed assets

$(1)$

Fixed assets to total assets

EBITDA

$-0.44 * * * \quad-0.41 * * *$

Sales to fixed assets

$0.00 \quad 0.00$

Total assets, $\log$

$0.001 \quad 0.001 *$

Total debt to common equity

$-1.94 * * \quad-2.04 *$

Market to book ratio

Foreign sales to total sales (FSTS)

$-0.06 * * * \quad-0.06 * *$

Post-referendum dummy

$0.02 * * * \quad 0.02 * *$

$0.01 \quad-0.01$

FSTS* post-referendum

$2.23-0.003$

FSTS*WTO Trade Costs*post-referendum

0.19

$0.25 *$

Interest rate on debt

Constant

$-0.01 *-0.01 * *$

Sector dummies

Observations

$71.85 * * * \quad 74.06 * * *$

R-squared

512

426

Robust standard errors (clustered at sector level)

$* * * \mathrm{p}<0.01, * * \mathrm{p}<0.05, * \mathrm{p}<0.1$

Notes: The dependent variable is capital expenditure in 6 quarters between 2014Q1 and 2015Q2 or between 2016Q1 and 2017Q2, in percent of end-2013 or end-2015 fixed assets, respectively. Net book value of plants, machinery and equipment is used as a measure of fixed assets. All control variables are as of end-2013 or end-2015, and in percent terms unless otherwise specified. For the FSTS I use the average annual value between 2013-2015 to include also firms for which FSTS is reported only every few years. In column (2) the effective interest rate on outstanding debt is added as an explanatory variable 